\title{
In vitro biomimetic deposition of apatite on alkaline and heat treated Ti6Al4V alloy surface
}

\author{
K FATEHI, F MOZTARZADEH, M SOLATI-HASHJIN, M TAHRIRI*, \\ M REZVANNIA and R RAVARIAN \\ Biomaterial Group, Faculty of Biomedical Engineering, Amirkabir University of Technology, \\ P.O. Box 15875-4413, Tehran, Iran
}

MS received 23 September 2007; revised 26 January 2008

\begin{abstract}
Titanium alloy (Ti6Al4V) substrates, having the ability of biomimetic calcium phosphate-based materials, especially hydroxyapatite deposition in a simulated body fluid (SBF) means of chemical treatment (alkaline treatment) and subsequent heat treatment, was studied. The effects of alkaline treatment time, concentration and heat treatment temperature on the formation of calcium phosphate (carbonate-hydroxyapatite) on Ti6Al4V surface were examined. For this purpose, the metallic substrates were treated in 0,5 and $10 \mathrm{M}$ $\mathrm{NaOH}$ solutions at a temperature of 60 or $80^{\circ} \mathrm{C}$ for 1 and 3 days. Subsequently the substrate was heat-treated at 500,600 and $700^{\circ} \mathrm{C}$ for $1 \mathrm{~h}$ for consolidation of the sodium titanate hydrogel layer. Finally, they were soaked in SBF for 1 and 3 days. The substrate surfaces were characterized by the techniques commonly used for bulk material such as scanning electron microscopy (SEM) and thin film X-ray diffraction (TF-XRD). With regard to the SEM and TF-XRD results, the optimum process consists of 3 days soaking in $5 \mathrm{M} \mathrm{NaOH}$ in $80^{\circ} \mathrm{C}$ and subsequent heat treatment at $600^{\circ} \mathrm{C}$ for $1 \mathrm{~h}$. It is worth mentioning that the results showed that the apatite formed within 3 days on the specimen surfaces, however, there was no sign of apatite formation in the control samples (without alkaline and heat treatment) which was treated for up to 3 days immersion in SBF.
\end{abstract}

Keywords. Ti6Al4V; apatite; biomimetic deposition; alkaline; heat treatment; SBF.

\section{Introduction}

Hydroxyapatite $\left(\mathrm{HA}: \mathrm{Ca}_{10}\left(\mathrm{PO}_{4}\right)_{6}(\mathrm{OH})_{2}\right)$ is an important material for bone and tooth implants, not only because its chemical composition is similar to that of bone tissues, but also it chemically bonds to bones. Owing to the inferior mechanical properties of HA, its application has been limited in clinics (Liu et al 2005). On the other hand, titanium (Ti) and its alloys, Ti6 Al4V, for example, are the materials of choice for most dental and orthopedic applications (Shibata et al 2003). The many advantages of these materials include biocompatibility, good resistance to corrosion, and excellent mechanical properties (Bigi et al 2005). However, titanium based materials are unfortunately not bioactive materials and generally encapsulated after implantation into the living body by fibrous tissue that isolates them from the surrounding bone (Yan and Davies 1998; Nishiguchi et al 1999). Therefore, coating titanium and its alloys with HA and other bioactive ceramic materials including surface modification becomes a popular method for providing them with a bone-bonding ability (Nishio et al 2001; Costantini et al 2002). These over-coatings could bond to living bone without forma-

*Author for correspondence (m-tahriri@aut.ac.ir) tion of fibrous tissue. These materials create a bone-like apatite (carbonate-hydroxyapatite) layer on their surface after implantation (Jonásová et al 2004). Therefore, apatite formation is believed to be the main requirement for bonebonding ability of materials in our understanding of the bioactive behaviour. The formation of a bone-like apatite surface layer can be reproduced in an acellular simulated body fluid ( $\mathrm{SBF}$ ) with ion concentration nearly equal to those of inorganic part of human blood plasma (Jonásová et al 2002).

Various methods of coating the surface of titanium and its alloys have been tested (de Groot et al 1987; Klein et al 1991) in order to combine the mechanical properties of

Table 1. Composition of SBF and the inorganic part of human blood plasma (mmol/l) (Teixeira et al 2004).

\begin{tabular}{lcc}
\hline Ion & Plasma $(\mathrm{mmol} / \mathrm{l})$ & $\mathrm{SBF}(\mathrm{mmol} / \mathrm{l})$ \\
\hline $\mathrm{Na}^{+}$ & $142 \cdot 0$ & $142 \cdot 0$ \\
$\mathrm{~K}^{+}$ & $5 \cdot 0$ & $5 \cdot 0$ \\
$\mathrm{Mg}^{+2}$ & $1 \cdot 5$ & $1 \cdot 5$ \\
$\mathrm{Ca}^{+2}$ & $2 \cdot 5$ & $2 \cdot 5$ \\
$\mathrm{Cl}^{-}$ & $103 \cdot 0$ & $147 \cdot 8$ \\
$\mathrm{HCO}_{3}^{-}$ & 27 & $4 \cdot 2$ \\
$\mathrm{HPO}_{4}^{-2}$ & $1 \cdot 0$ & $1 \cdot 0$ \\
$\mathrm{SO}_{4}^{-2}$ & $0 \cdot 5$ & $0 \cdot 5$ \\
\hline
\end{tabular}



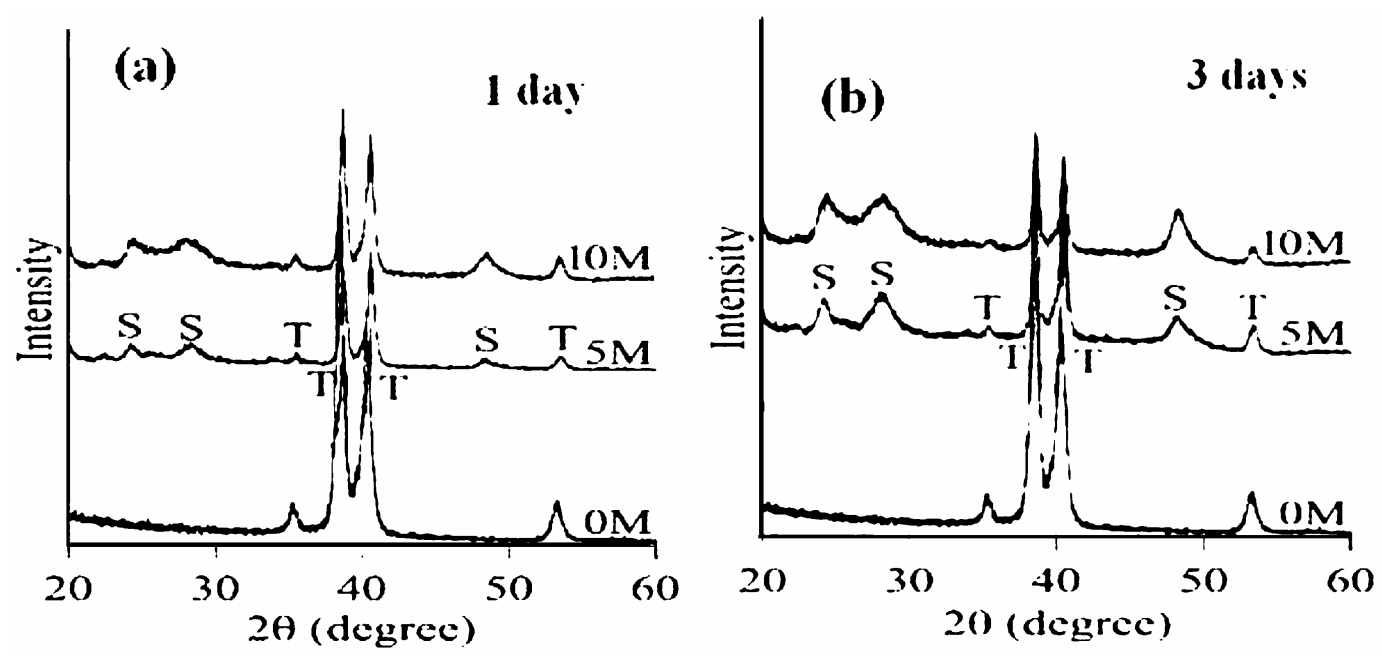

Figure 1. TF-XRD patterns for the specimens subjected to 0,5 and $10 \mathrm{M} \mathrm{NaOH}$ treatment at $60^{\circ} \mathrm{C}$ for (a) 1 and (b) 3 days ( $\mathrm{T}$, titanium and $\mathrm{S}$, sodium titanate).
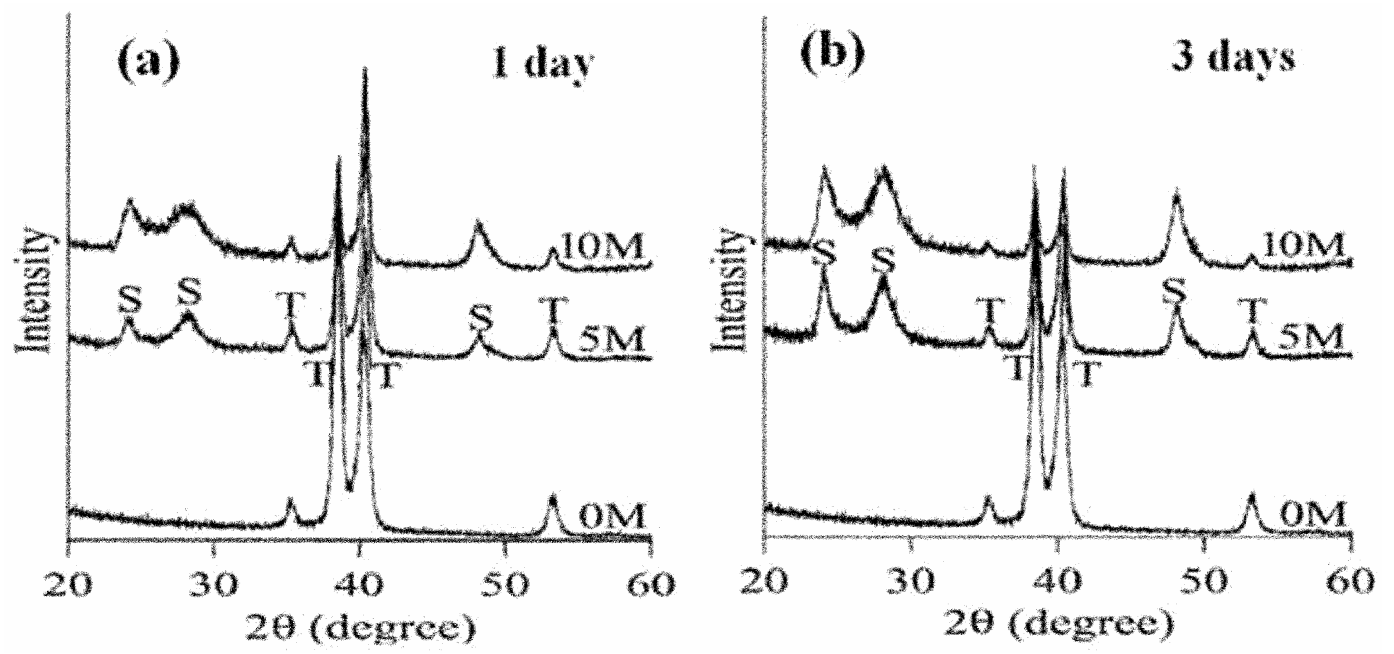

Figure 2. TF-XRD patterns for the specimens subjected to 0,5 and $10 \mathrm{M} \mathrm{NaOH}$ treatment at $80^{\circ} \mathrm{C}$ for (a) 1 and (b) 3 days ( $\mathrm{T}$, titanium and $\mathrm{S}$, sodium titanate).

metals with bone-bonding ability of bioactive ceramic materials. Titanium alloys coated with plasma-sprayed HA is currently used for orthopedic applications. By this method, HA powder is heated at extremely high temperatures and deposited on the metal surface with very high velocity.

Recently, several groups have focused their attention on low temperature deposition methods such as electrophoretic (Wei et al 1999), electrochemical (Monma 1994) and biomimetic (Jonásová et al 2004). The biomimetic process is a physicochemical method in which a substrate is soaked in a solution that simulates the physiologic conditions (SBF), for a period of time, long enough to form a desirable layer of calcium phosphate on the substrate surface. In contrast to plasma spraying, biomimetic methods offer the possibility to cover complex shaped implants and elaborate on films of different $\mathrm{Ca}-\mathrm{P}$ phases (Kokubo et al 1989; Barrere et al 1999). In recent years, different metal pretreatments, such as alkaline treatment (Kim et al 1997), acid treatment (Wen et al 1998), have been used for accelerating and enhancing the biomimetic coating activity.

In this study, Ti6Al4V substrates were provided with in vitro apatite-forming ability by means of combined chemical (alkaline) and heat treatment.

\section{Materials and methods}

\subsection{Sample preparation}

Thirtysix Ti6Al4V (ASTM [American Society for testing of Materials] F620: standard specification for alpha plus 

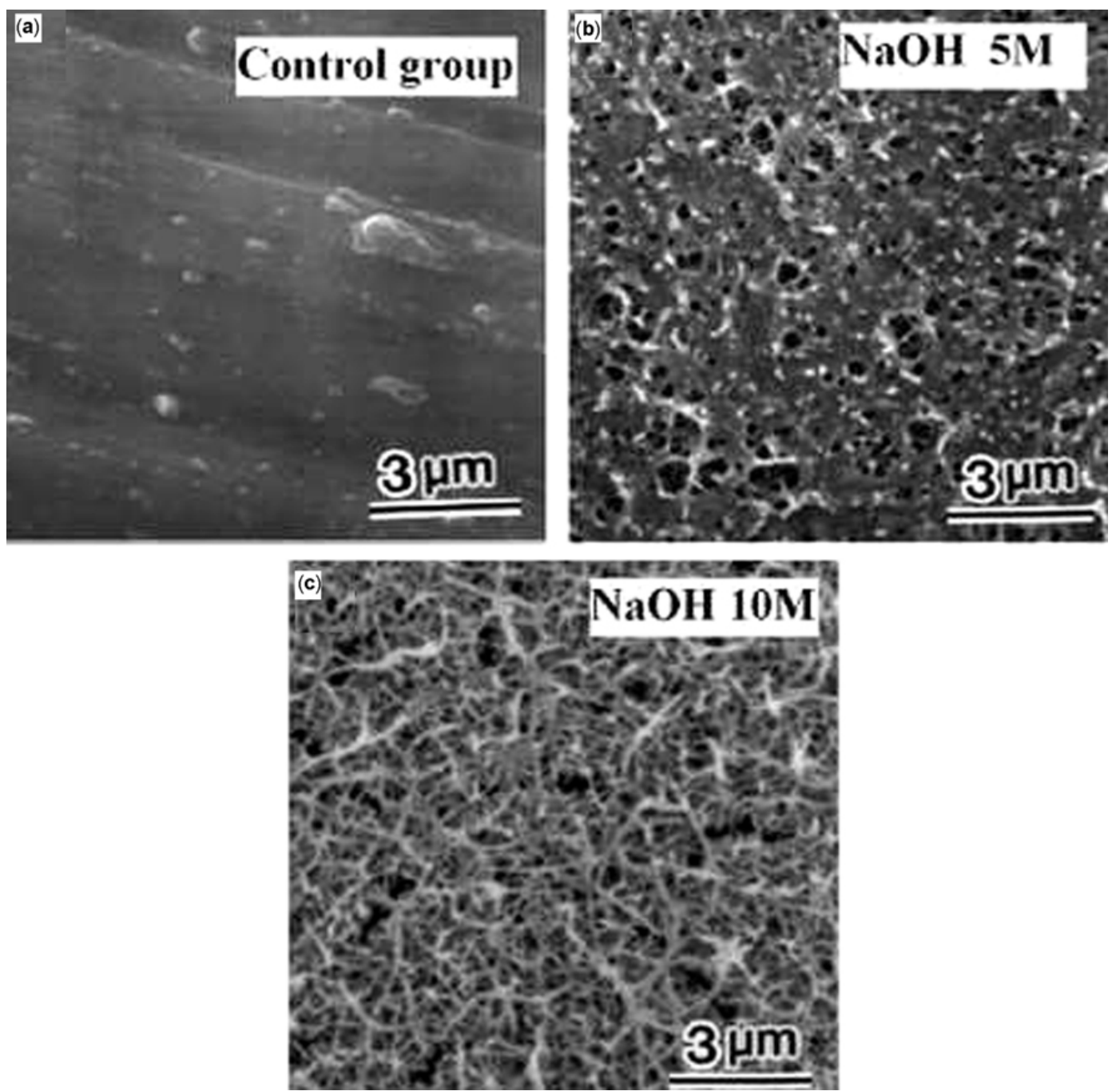

Figure 3. Surface morphologies (by SEM) for the specimens subjected to (a) 0 (control group), (b) 5 and (c) $10 \mathrm{M} \mathrm{NaOH}$ treatment at $60^{\circ} \mathrm{C}$ for 3 days.

beta titanium alloy forgings for surgical implants) discs each of $20 \mathrm{~mm}$ diameter and $5 \mathrm{~mm}$ thickness were polished with 200-, 400- and 600-grit silicon carbide ( $\mathrm{SiC})$ paper. Then these discs were cleaned by successive ultrasonic treatments for $15 \mathrm{~min}$ in acetone first, secondly, in $70 \%$ ethanol, and finally in double distilled water, and subsequently the discs were dried in air. The discs were divided into three groups (12 discs per group) and subjected to the following treatment: (i) control group without any treatment, (ii) the alkaline and heat treated samples and (iii) the alkaline and heat treated samples that were postheated at various temperatures.

\subsection{Alkaline treatment}

The Ti6Al4V alloy discs (second group) were soaked in $\mathrm{NaOH}$ solution at a concentration of 5 and $10 \mathrm{M}$, respectively. Two treatment temperatures were used (60 and $80^{\circ} \mathrm{C}$ ) in which the specimens were treated at either temperature for 1 or 3 days. Following the treatment, the speci- mens were slowly washed with distilled water and dried at $40^{\circ} \mathrm{C}$ in an electric oven for overnight.

\subsection{Heat treatment}

The Ti6Al4V alloy discs (third group) were alkalinetreated with 5 and $10 \mathrm{M} \mathrm{NaOH}$ at $60^{\circ} \mathrm{C}$ and $80^{\circ} \mathrm{C}$ for 1 and 3 days, after which they were washed and dried as described in the previous section. The specimens were then heat-treated at 500,600 or $700^{\circ} \mathrm{C}$ for $1 \mathrm{~h}$ in a $\mathrm{Ni}-\mathrm{Cr}$ electrical furnace in air and cooled to ambient temperature in the furnace.

\subsection{Preparation of $S B F$}

The SBF solution was prepared by dissolving reagent-grade $\mathrm{NaCl}, \mathrm{KCl}, \mathrm{NaHCO}_{3}, \mathrm{MgCl}_{2} \cdot 6 \mathrm{H}_{2} \mathrm{O}, \mathrm{CaCl}_{2}$ and $\mathrm{KH}_{2} \mathrm{PO}_{4}$ into distilled water and buffered at $\mathrm{pH}=7.25$ with trishydroxymethyl aminomethane (TRIS) and $\mathrm{HCl} 1 \mathrm{~N}$ (1 normal 

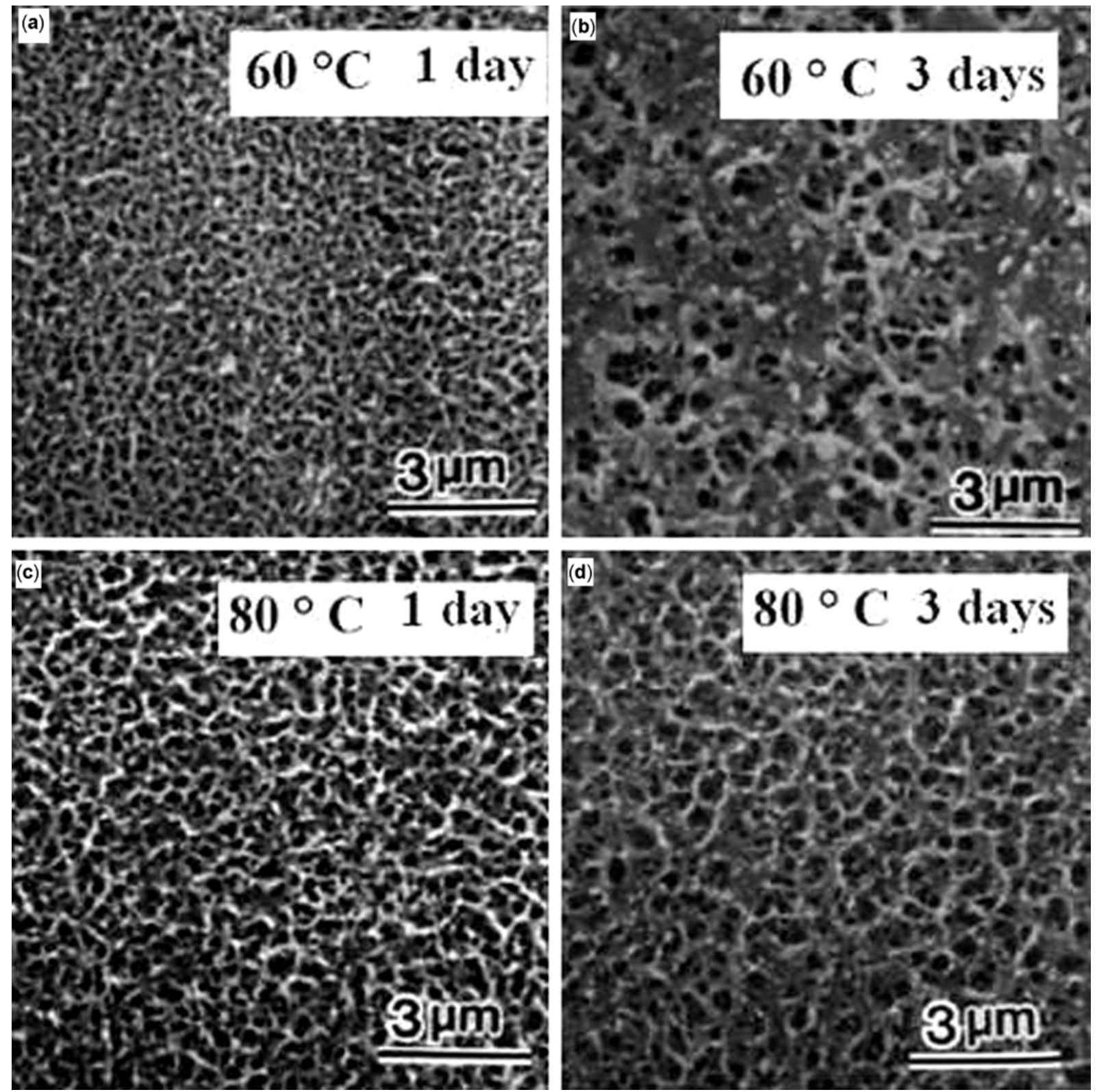

Figure 4. Surface morphologies (by SEM) for the specimens subjected to $5 \mathrm{M} \mathrm{NaOH}$ treatment at (a) $60^{\circ} \mathrm{C}$ for 1 day, (b) $60^{\circ} \mathrm{C}$ for 3 days, (c) $80^{\circ} \mathrm{C}$ for 1 day and (d) $80^{\circ} \mathrm{C}$ for 3 days.

(N) $\mathrm{HCl}=36.5 \mathrm{~g} / \mathrm{L}$ ) at $37^{\circ} \mathrm{C}$. Its composition is given in table 1 and is compared with the human blood plasma. The discs were then soaked in $30 \mathrm{ml} \mathrm{SBF}$ solution at $37^{\circ} \mathrm{C}$ for 1 or 3 days.

\section{Surface characterization}

The morphological investigations of the specimens before and after alkaline and heat treatment and soaking in SBF were performed by using scanning electron microscope (SEM). The specimens were coated with a thin layer of gold $(\mathrm{Au})$ (thickness $=20 \mathrm{~nm}$ ) by sputtering process for better observation of surface morphology of specimens before taking images from SEM. The effects of alkaline treatment on the surface of the substrate and the structure of the titanium substrate, gel layer and bone-like apatite coatings obtained were analysed by thin film X-ray diffraction (TF-XRD). All specimens were examined at $2 \theta$ Bragg angles from $20^{\circ}$ to $60^{\circ}$ at a scanning speed of $0 \cdot 02 \% \mathrm{~min}$.

\section{Results and discussion}

Figures 1 and 2 show the TF-XRD patterns of the surfaces of the $\mathrm{NaOH}$-treated $\mathrm{Ti} 6 \mathrm{Al} 4 \mathrm{~V}$ alloy subjected to heat treatment at various temperatures for various time periods. 
od

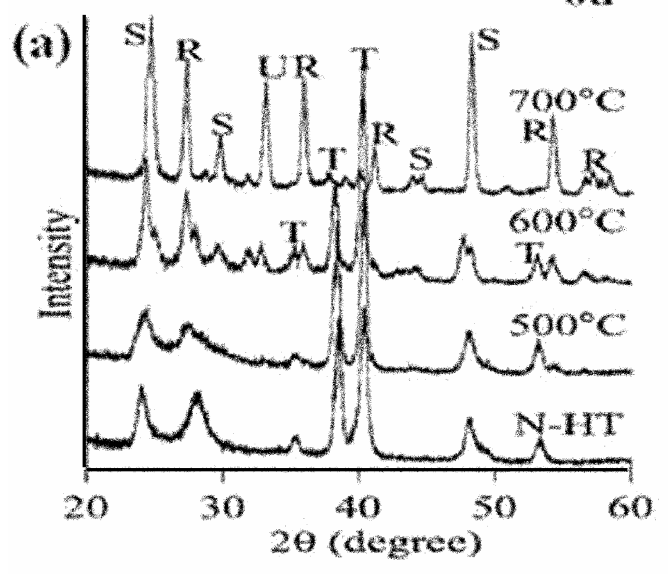

$1 \mathrm{a}$

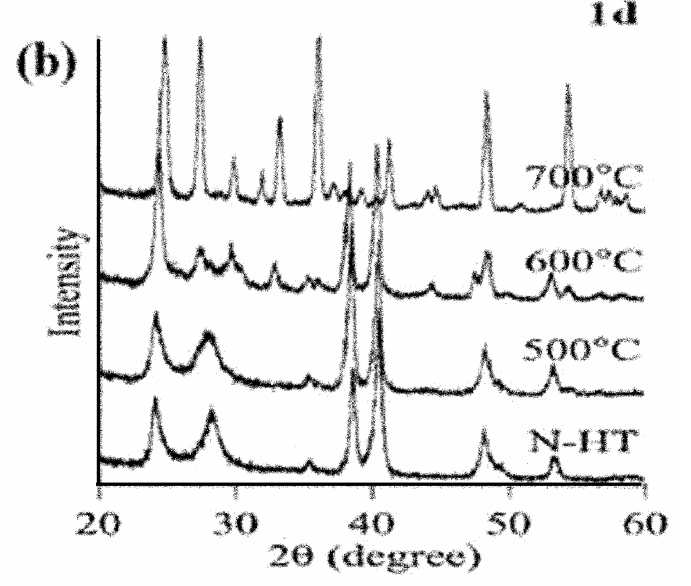

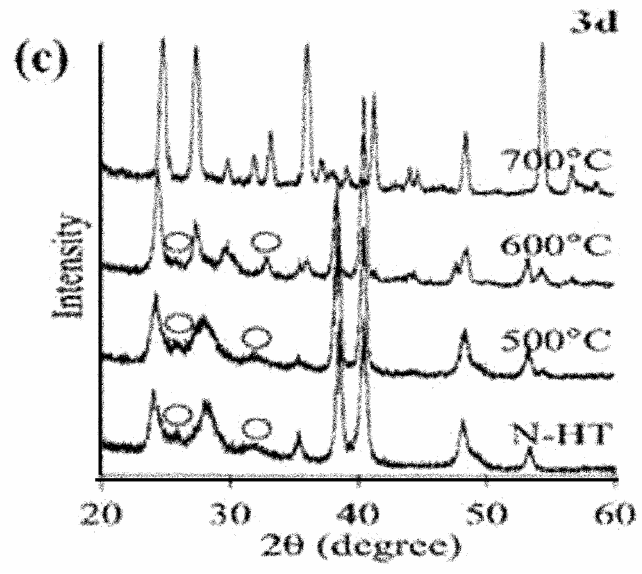

Figure 5. TF-XRD patterns for the specimens subjected to $5 \mathrm{M} \mathrm{NaOH}$ treatment at $80^{\circ} \mathrm{C}$ for 3 days without heat treatment $(\mathrm{N}-\mathrm{HT})$ or heat-treated at 500,600 or $700^{\circ} \mathrm{C}$ for $1 \mathrm{~h}$, and soaked in SBF for (a) 0 , (b) 1 and (c) 3 days ( $R$, rutile; T, titanium; S, sodium titanate; $\mathrm{O}$, apatite and $\mathrm{U}$, unknown).

Assignments of the main diffraction peaks are given in figures 1 and 2 . New broad diffraction peaks appeared around $23-30^{\circ}$ and $47-49^{\circ}$ in $2 \theta$ after the $\mathrm{NaOH}$ treatment. These peaks can be ascribed to an amorphous (partially crystalline) or a microcrystalline phase. Also these peaks can be attributed to the sodium titanate hydrogel layer formed by alkaline treatment which is responsible for apatite formation (Kokubo et al 1989). The leaching of Ti6Al4V in $\mathrm{NaOH}$ does not seem to completely dissolve the passive oxide layer (generally, titanium and its alloys are covered with a passive oxide layer $\left.\left[\mathrm{TiO}_{2}\right]\right)$. Upon exposure to $\mathrm{NaOH}$, this passive layer partially dissolves to form $\mathrm{HTiO}^{3-}$. Simultaneously, titanium is hydrated to form $\mathrm{HTiO}^{3-} \cdot n \mathrm{H}_{2} \mathrm{O}$. These negatively charged groups react with positively charged alkali ions $\left(\mathrm{Na}^{+}\right)$to produce an alkali titanate hydrogel layer (sodium titanate hydrogel) on the alloy surface (Takadama et al 2001).

At the same treating temperature and period of time, the sodium titanate peak heights increased with increasing concentration of $\mathrm{NaOH}$ treatment solution. This is because more $\mathrm{Na}^{+}$ions are incorporated into the metal surface, and the thickness of the gel layer increases with increasing concentration of the $\mathrm{NaOH}$ solution, alkalinetreating time, and alkaline-treating temperature. However, it was found that in higher concentration of more than $10 \mathrm{M} \mathrm{NaOH}$, thick sodium titanate film peeled off either during alkaline treatment itself or later during water rinsing. Similar intensities of sodium titanate peaks were detected for all specimens treated with 5 or $10 \mathrm{M}$ $\mathrm{NaOH}$ at $80^{\circ} \mathrm{C}$ for 3 days. Thus, the least aggressive treatment resulting in the thickest layer of sodium titanate was to soak in $5 \mathrm{M} \mathrm{NaOH}$ solution at $80^{\circ} \mathrm{C}$ for 3 days among the trials of this experiment.

Figure 3 shows SEM photographs of the surfaces of control specimen and the $\mathrm{NaOH}$-treated Ti6Al4V alloy subjected to 0,5 and $10 \mathrm{M} \mathrm{NaOH}$ treatment at $60^{\circ} \mathrm{C}$ for 3 days. The SEM photograph revealed that the control specimen had a smooth surface texture with abrasive marks (figure $3 \mathrm{a}$ ). In contrast, the alkaline-treated and the alkaline- and heat-treated titanium alloys had porous surfaces. At the same alkaline-treating temperature, a much porous structure was observed with increasing treatment time (figures $3 \mathrm{~b}, \mathrm{c}$ ). At a constant alkaline concentration, more homogeneously distributed porous surface structure 

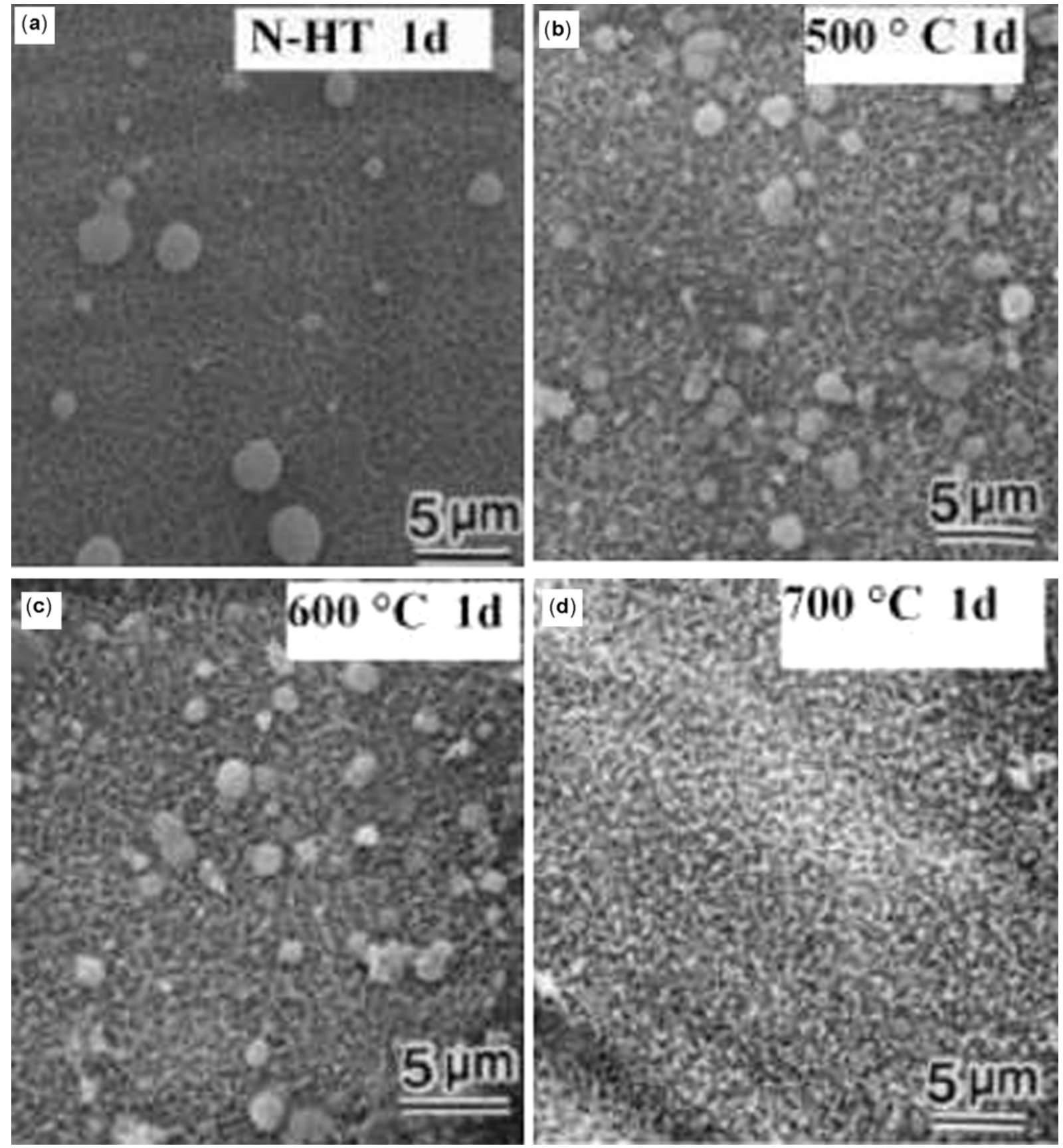

Figure 6. Surface morphologies (by SEM) for the specimens subjected to $5 \mathrm{M} \mathrm{NaOH}$ treatment: (a) without heat treatment $(\mathrm{N}-\mathrm{HT})$ and heat-treated at (b) 500, (c) 600 and (d) $700^{\circ} \mathrm{C}$ for $1 \mathrm{~h}$ and soaked in SBF for 1 day.

was observed for the specimens treated at $80^{\circ} \mathrm{C}$ than for those treated at $60^{\circ} \mathrm{C}$ (see figure 4 ).

After soaking the specimens in SBF, it was clearly observed in the XRD patterns (figure 5) that apatite was formed on the surface of the specimens treated with $5 \mathrm{M}$ $\mathrm{NaOH}$ at $80^{\circ} \mathrm{C}$ for 3 days when soaked in SBF for 1 day, either with or without heat treatment at 500 or $600^{\circ} \mathrm{C}$ for $1 \mathrm{~h}$. However, apatite was not formed on the surface of the specimens which was heat-treated at $700^{\circ} \mathrm{C}$. The lack of apatite formation on these specimens may be attributed to the surface structure-changes produced by the heat treatment. The $\mathrm{Na}^{+}$ions from the amorphous layer during SBF soaking exchange with $\mathrm{H}_{3} \mathrm{O}^{+}$ions produced in the surrounding fluid resulting in $\mathrm{Ti}-\mathrm{OH}$ layer formation (Kokubo 1996; Takadama et al 2001). Simultaneously, with increasing $\mathrm{pH}$ the apatite nucleation gets accelerated on increasing the supersaturation of the solution with respect to apatite. Calcium ions $\left(\mathrm{Ca}^{2+}\right)$ are incorporated in the hydrated $\mathrm{Ti}-\mathrm{OH}$ layer. The positively charged $\mathrm{Ca}^{2+}$ may act as nucleation sites for carbonate-hydroxyapatite 

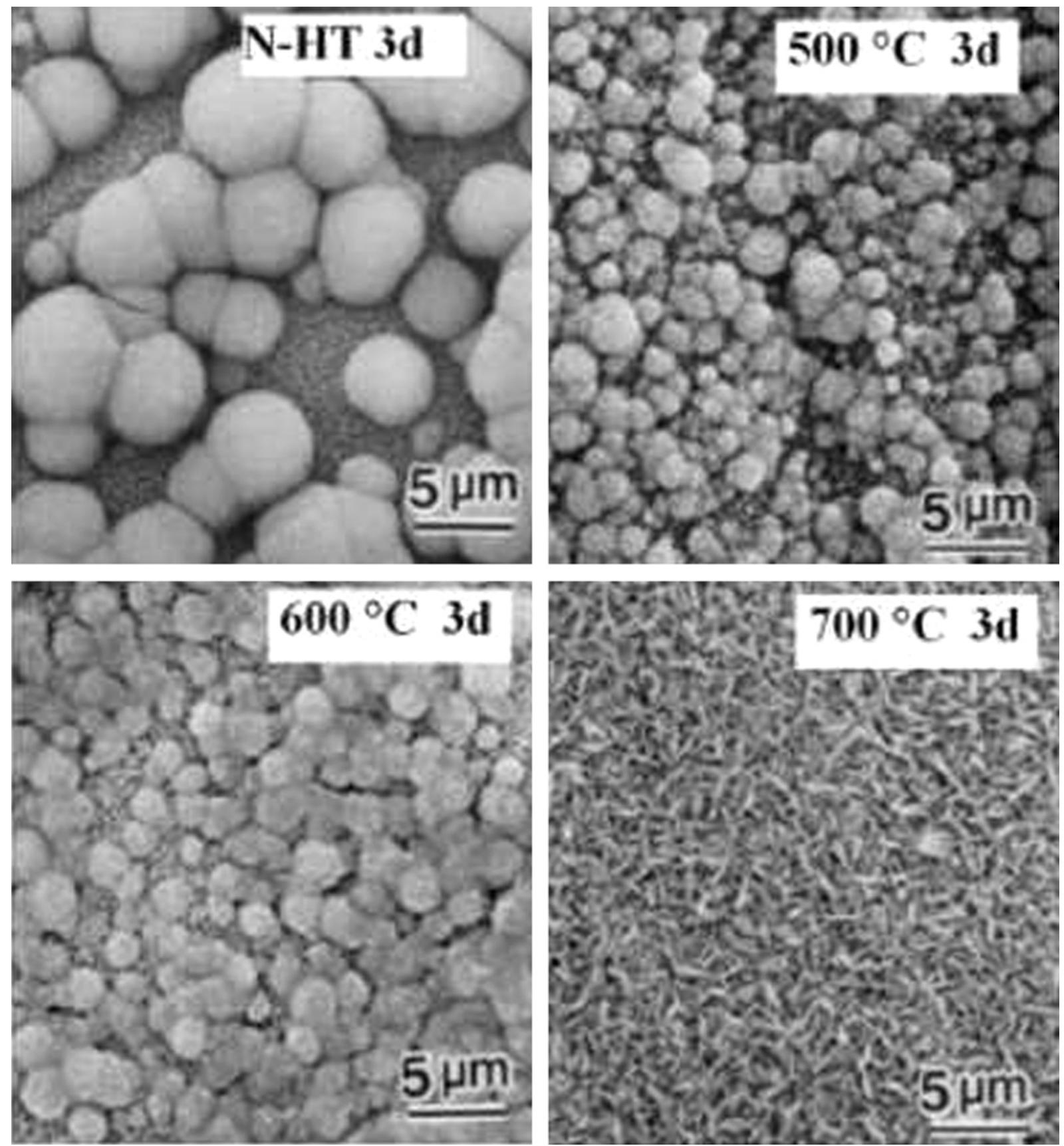

Figure 7. Surface morphologies (by SEM) for the specimens subjected to $5 \mathrm{M} \mathrm{NaOH}$ treatment (a) without heat treatment $(\mathrm{N}-\mathrm{HT})$ and heat-treated at (b) 500, (c) 600 and (d) $700^{\circ} \mathrm{C}$ for $1 \mathrm{~h}$ and soaked in SBF for 3 days.

by attaching themselves to the negatively charged $\left(\mathrm{PO}_{4}^{3-}\right)$ and $\left(\mathrm{CO}_{3}^{2-}\right)$ to form $\mathrm{Ca}-\mathrm{P}$ enriched surface layer which crystallizes to bone-like apatite (carbonate-hydroxyapatite) (Jonásová et al 2004). The apatite formation on chemically treated Ti6Al4V alloy seems to be similar to that on bioactive glasses. The sodium ions $\left(\mathrm{Na}^{+}\right)$released from the glass substrate via exchange with the $\mathrm{H}_{3} \mathrm{O}^{+}$or $\mathrm{H}^{+}$ions in the SBF form the Ti-OH groups on their surfaces (Yan et al 1997; Kim et al 2003; Teixeira et al 2004). This was described to induce apatite nucleation via incorporation of $\mathrm{Ca}^{2+}$ or increasing the $\mathrm{OH}^{-}$concentration. The consumption of $\mathrm{H}_{3} \mathrm{O}^{+}$causes an increase in the $\mathrm{pH}$ concentra- tion and an increase in apatite forming (Hench 1991). However, at a relatively high sintering temperature $\left(700^{\circ} \mathrm{C}\right)$, the surface structure becomes more stable and less sodium ions are released from the substrate, therefore, less $\mathrm{TiOH}$ groups were formed (Yan et al 1997).

At room temperature $\left(25^{\circ} \mathrm{C}\right)$, many $\mathrm{TiOH}$ groups were found on the surface of the specimens, and hence, apatite was easily formed with large size particles. However, it seems that they were weakly bonded to the substrate. Figures 6 and 7 show SEM photographs of Ti6Al4V alloy treated with $5 \mathrm{M} \mathrm{NaOH}$ solution at $80^{\circ} \mathrm{C}$ for 3 days, without heat treatment or heat-treated at 500, 600 or 
$700^{\circ} \mathrm{C}$ for $1 \mathrm{~h}$, and soaked in SBF for 1 and 3 days. Relatively small apatite crystals were formed on the specimens which were heat-treated at both 500 and $600^{\circ} \mathrm{C}$. This formation might be caused due to the reduction of the number of $\mathrm{TiOH}$ groups on the surface of the heat-treated specimens. However, apatite coverage on the heat treated specimens at $600^{\circ} \mathrm{C}$ is more than that at $500^{\circ} \mathrm{C}$.

According to above explanations, it was determined that the best treatment conditions for Ti6Al4V specimens were immersed in $5 \mathrm{M} \mathrm{NaOH}$ solution at $80^{\circ} \mathrm{C}$ for 3 days followed by heat treatment at $600^{\circ} \mathrm{C}$ for $1 \mathrm{~h}$.

\section{Conclusions}

Titanium alloy (Ti6Al4V) treated in $\mathrm{NaOH}$ can form apatite after soaking in SBF. It was found that after soaking in $\mathrm{SBF}$, the Ti-OH groups formed on the alloy via exchange of $\mathrm{Na}^{+}$ions with $\mathrm{H}_{3} \mathrm{O}^{+}$ions which induced apatite formation indirectly by forming an amorphous sodium titanate layer on the Ti6Al4V surface. Therefore, alkaline and heat treatment are effective pre-treatment methods for apatite formation on the Ti6Al4V surface with optimum conditions of 3-day soaking in $5 \mathrm{M} \mathrm{NaOH}$ solution at $80^{\circ} \mathrm{C}$ and then heat treatment at $600^{\circ} \mathrm{C}$ for $1 \mathrm{~h}$.

Finally, it is worth mentioning that Ti6Al4V shows a fairly high apatite-forming ability in a body-like environment. Hence, it has a high bone-bonding ability, as well as mechanical stability of its surface when subjected to a $\mathrm{NaOH}$ treatment and subsequent heat treatment to form an amorphous sodium titanate layer on its surface. Thus, treated Ti6Al4V is believed to be useful as a bone substitute.

\section{References}

Barrere F, Layrolle P, Van Blitterswijk C A and de Groot K 1999 Bone 25107
Bigi A, Boanini E, Bracci B, Facchini A, Panzavolta S, Segatti $\mathrm{F}$ and Sturba L 2005 Biomaterials 26/19 4085

Costantini A, Luciani G, Branda F, Ambrosio L, Mattogno G and Pandolfi L 2002 J. Mater. Sci. Mater. Med. 13891

de Groot K, Geesink R G, Klein C P and Serekian P 1987 J. Biomed. Mater. Res. 211375

Hench L L 1991 Am. Ceram. Soc. 741487

Jonásová L, Helebrant A and Sanda L 2002 Ceram-Silikáty 469

Jonásová L, Müller A F, Helebrant A, Strand J and Greil P 2004 Biomaterials 251187

Kim H M, Miyaji F, Kokubo T and Nakamura T 1997 J. Biomed. Mater. Res. 38121

Kim H M, Kokubo T and Awashita M 2003 Biomaterials 24 2161

Klein C P, Patka P, van der Lubbe H, Wolke J G and de Groot K 1991 J. Biomed. Mater. Res. 2553

Kokubo T 1996 Thermochim. Acta 280479

Kokubo T, Kushitani H, Abe Y and Yamamuro T 1989 Bioceramics 2235

Liu F, Song Y, Wang F, Shimizu T, Igarashi $\mathrm{K}$ and Zhao L 2005 J. Biosci. Bioeng. 100100

Monma H 1994 J. Mater. Sci. 29949

Nishiguchi S, Nakamura T, Kobayashi M, Kim H M, Miyaji F and Kokubo T 1999 Biomaterials 20491

Nishio K, Neo M, Akiyama H, Nishiguchi S, Kim H, Kokubo T and Nakamura T 2001 J. Mol. Struct. 596191

Shibata K, Tsuru K, Hayakawa S and Osaka A 2003 Key Eng. Mater. 24055

Takadama H, Kim H M, Kokubo T and Nakamura T $2001 \mathrm{~J}$. Biomed. Mater. Res. 57441

Teixeira R L P, Godoy G C D and Pereira M M 2004 Mater. Res. 7299

Wei M, Ruys A J, Milthorpe B K and Sorrell C C 1999 J. Biomed. Mater. Res. 4511

Wen H B, Liu Q, de Wijn J R, de Groot K and Cui F Z 1998 J. Mater. Sci. Mater. Med. 9121

Yan W Q and Davies J E 1998 Bioceramics 11659

Yan W Q, Nakamura T, Kawanabe K, Nishigochi Sh, Oka M and Kokubo T 1997 Biomaterials 181185 